\title{
PENERAPAN MODEL PEMBELAJARAN GROUP INVESTIGATION (GI) UNTUK MENINGKATKAN HASIL BELAJAR IPA KELAS V
}

\author{
N.L.Pt. Muliyantini ${ }^{1}{ }^{*}$, Dsk. Pt. Parmiti ${ }^{2}$ \\ ${ }^{1}$ Universitas Pendidikan Ganesha \\ ${ }^{2}$ Universitas Pendidikan Ganesha
}

\begin{abstract}
Abstrak
Penelitian ini bertujuan untuk mengetahui peningkatan hasil belajar IPA setelah penerapan model pembelajaran Group Investigation (GI) siswa kelas V SD No. 1 Abianbase. Jenis penelitian ini adalah Penelitian Tindakan Kelas. Penelitian ini dilaksanakan dalam dua siklus. Data hasil belajar IPA dikumpulkan dengan tes hasil belajar IPA dan dianalisis menggunakan metode analisis deskriptif kuantitatif. Penelitian ini menggunakan metode observasi dan metode tes. Berdasarkan data yang diperoleh pada siklus I hasil belajar siswa $66,67 \%$ berada pada kategori sedang.Pada siklus II hasil belajar siswa $90,91 \%$ berada pada kategori sangat tinggi. Terjadi peningkatan hasil belajar siswa sebesar 24,24\% dari siklus I ke siklus II. Berdasarkan analisis dan pembahasan disimpulkan bahwa penerapan model pembelajaran Group Investigation (GI) dapat efektif meningkatkan hasil belajar IPA, materi sifat bahan dan struktur penyusunnya pada siswa kelas V SD No. 1 Abianbase.
\end{abstract}

\author{
Keywords: \\ Group Investigation, \\ Hasil Belajar, IPA
}

\section{Pendahuluan}

Pendidikan merupakan kebutuhan sepanjang hayat. Setiap manusia membutuhkan pendidikan sampai kapan dan dimanapun berada. Pendidikan sering diartikan sebagai usaha manusia untuk membina kepribadiannya sesuai dengan nilai-nilai di dalam masyarakat dan kebudayaan (Hasbullah, 2011). Pendidikan sangat penting artinya, sebab tanpa pendidikan manusia sulit berkembang dan bahkan hidup terbelakangan. Dengan demikian pendidikan harus betul-betul diarahkan untuk menghasilkan manusia yang berkualitas dan mampu bersaing di era globalisasi, di samping ditunjang dengan memiliki budi pekerti yang luhur dan moral yang baik.

Namun pada kenyataanya masih terdapat berbagai macam permasalahan yang berhubungan dengan dunia pendidikan khususnya di tingkat sekolah dasar. Permasalahan yang sering muncul yaitu masih rendahnya kualitas pendidikan siswa yang disebabkan oleh kurang profesionalnya tenaga pengajar (guru). Secara umum guru belum sepenuhnya mampu memberikan pelayanan kepada siswa dengan memberikan pembelajaran yang berkualitas dan mampu membentuk watak siswa melalui pengembangan dan nilai-nilai yang diinginkan. Guru harus mampu menjalankan tugas dan tanggungjawabnya untuk dapat meningkatkan kualitas dari sumber daya manusia. Apabila guru sudah mampu menjalankan tugas dan tanggungjawabnya dengan baik dan profesional maka tujuan pendidikan nasional yaitu untuk mencerdaskan kehidupan bangsa dapat tercapai.

Salah satu kekurangan guru selama membelajarkan siswa yaitu guru sebagian besar belum mampu mengusai materi pembelajaran secara keseluruhan, terutama pada mata pelajaran yang memiliki ruang lingkup dan bahasan materi yang luas dan padat. Salah satunya terdapat pada mata pelajaran IPA. Mata pelajaran IPA merupakan salah satu mata pelajaran yang memiliki cakupan materi yang cukup luas dan padat. Sehingga kemampuan guru dalam menyajikan materi pada mata pelajaran IPA harus dipersiapakan dengan baik. Apabila guru kurang mampu menyajikan materi tersebut dengan baik dan semenarik mungkin, maka dapat mengakibatkan siswa menjadi bosan dan jenuh selama kegiatan pembelajaran berlangsung. Hal tersebut yang nantinya dapat menyebabkan merosotnya hasil belajar siswa pada mata pelajaran IPA itu sendiri.

Dalam kurikulum KTSP (2008) menyatakan bahwa Ilmu pengetahuan Alam (IPA) berhubungan dengan cara mencari tahu tentang alam secara sistematis, sehingga IPA bukan hanya penguasaan kumpulan pengetahuan yang berupa fakta-fakta, konsep-konsep, atau prinsip-prinsip saja tetapi juga merupakan suatu proses penemuan yang dikaitkan dengan fenomena alam yang terjadi dalam kehidupan

\footnotetext{
* Corresponding author.

E-mail Addresses: putu.muliyantini@yahoo.com (N.L.Pt. Muliyantini), dskpt_parmiti@yahoo.co.id (Dsk.Pt. Parmiti)
} 
sehari-hari. Pada hakekatnya IPA dipandang dari segi produk, proses dan dari segi pengembangan sikap. Artinya belajar IPA memiliki dimensi proses, dimensi hasil (produk) dan dimensi pengembangan sikap ilmiah. Pembelajaran IPA sebaiknya dilaksanakan secara ilmiah untuk menumbuhkan kemampuan berfikir, bekerja dan bersikap ilmiah serta mengkomunikasikan sebagai aspek penting kecakapan hidup (Julianto, dkk., 2011; Laba Laksana \& Dek Ngurah, 2016; Juniati, \& Widiana, 2017).

IPA adalah pengetahuan yang sistematis dan tersusun secara teratur, berlaku umum, dan berupa kumpulan data hasil observasi dan eksperimen (Depdiknas, 2006). Devi (2010) mengemukakan bahwa IPA berhubungan dengan cara mencari Tahu alam secara sistematis. Pelaksanaan proses pembelajaran IPA yang benarmencakup 4 komponen: (1) IPA sebagai produk, (2) IPA sebagai proses,(3) IPA sebagai sikap dan, (4) IPA sebagai teknologi (Cain dan Evans,1993 dalam Puspitasari, 2009). Subagyo (2009) menjelaskan bahwa cara mengajar IPA di SD perlu diubah dari bentuk pemindahan ilmu (transfer of knowledge) yang pasif menjadi pendekatan proses.

Kreativitas guru juga menjadi salah satu faktor penting dalam keberhasilan pembelajaran, guru yang kreatif akan memilih dan mengembangkan pembelajaran sesuai dengan kemampuan guru dan karakteristik mata pelajaran, kompetensi dasar, materi pembelajaran dan sisiwa serta bentuk pertanyaan siswa (Widiana, 2016). Guru harus mampu menciptakan pembelajaran yang aktif, kreatif serta menarik perhatian siswa, sehingga siswa merasa senang dan termotivasi dalam mengikuti proses belajar mengajar. Pentingnya guru berkreativitas, mengingat bahwa guru merupakan salah satu sumber belajar bagi siswa di dalam kelas. Terlebih lagi di sekolah dasar, guru harus mampu berkreativitas dengan melihat kecenderungan dan karakteristik anak usia sekolah dasar, mereka lebih senang bergerak dan melakukan sesuatu secara langsung. Oleh sebab itu, guru dituntut untuk mengembangan proses pembelajaran yang inovatif, menantang dan menyenangkan bagi siswa sehingga pembelajaran menjadi mudah diphami oleh siswa.

Salah satu cara yang dapat dilakukan untuk menciptakan pembelajaran yang kreatif, menantang, menyenangkan dan bermakna bagi siswa yaitu dengan menerapkan model pembelajaran. Menurut Sukmadinata (dalam Imas Kurniasih dkk, 2015) mengatakan bahwa "dasar pemilihan pembelajaran itu harus mencangkup model pembelajaran yang sesuai dengan karakteristik mata pelajaran, tujuan pembelajaran serta kemampuan siswa dan guru".

Fakta yang ada dilapangan bahwa guru kebanyakan masih kurang siap dalam menyajikan materi yang diberikan kepada siswa. Selain itu guru juga kurang kreatif dalam mengembangkan metode atau model pembelajaran yang digunakan selama kegiatan pembelajaran IPA tersebut berlangsung. Hal lain yang menyebabkan kegiatan pembelajaran terasa kurang menarik karena kurangnya kemampuan guru dalam mengembangkan dan memanfaatkan sumber belajar dan fasilitas penunjang yang dimiliki sekolah untuk menunjang kegiatan pembelajaran. Dengan mengembangkan dan memanfaatkan sumber belajar semaksimal mungkin dapat meningkatkan ketertarikan siswa selama mengikuti kegiatan pembelajaran.

Untuk membuktikan permasalah-permasalahan yang sering terjadi di sekolah dasar, maka dilakukan observasi dan wawancara di SD No. 1 Abianbase. Berdasarkan hasil observasi pada pembelajaran IPA siswa kelas V SD No. 1 Abianbase terlihat dalam pembelajaran IPA dimana guru masih berpedoman pada buku pelajaran saat mengembangkan materi pelajarannya. Metode yang digunakan tidak sesuai dengan karakteristik sehingga guru terkesan mendominasi pembelajaran dalam pembelajaran IPA. Disamping permasalahan pada kenyataan yang ditemui, masih banyak siswa menganggap IPA sebagai salah satu pelajaran yang sulit karena terlalu banyak teori dan fakta yang harus dihafalkan. Pembelajaran masih bersifat text book, guru tidak menambah sumber belajar lain yang dapat mendukung. Akibatnya pencapaian tujuan pembelajaranpun masih jauh dari standar yang telah diharapkan.

Berdasarkan hasil wawancara dengan guru bidang, hasil belajar siswa pada mata pelajaran IPA belum tercapai secara maksimal. Dilihat dari hasil ketuntasan minimal masih kurang dengan rata-rata 65 di bawah kriteria ketuntasan minimal (KKM) yang harus dicapai dalam mata pelajaran IPA adalah 74 . Berdasarkan data tersebut dilakukan identifikasi masalah untuk menemukan solusi yang terbaik dalam mengatasi permasalahan tersebut.

Masalah lain yang nampak adalah aktivitas belajar siswa yang rendah, anak tidak antusias dalam kegiatan pembelajaran, konsentrasi anak dalam menerima pelajaran juga kurang. Siswa merasa jenuh dengan penjelasan guru pada saat penyampaian materi pembelajaran karena hanya menggunakan metode ceramah setiap mengajar, masih rendahnya motivasi dan hasil belajar siswa serta siswa sering acuh pada saat mengikuti pelajaran dan pada saat guru menyampaikan materi pembelajaran. Siswa lebih banyak menunggu sajian dari guru daripada mencari dan menemukan sendiri pengetahuan, keterampilan, serta sikap yang harus dikuasainya. Akibatnya siswa menjadi kurang termotivasi untuk mengikuti pembelajaran. Siswa merasa bosan dan akhirnya mereka tidak memperhatikan pelajaran. 
Dari permasalahan di atas, diperlukan solusi yang tepat untuk meningkatkan hasil belajar IPA siswa kelas V SD No. 1 Abianbase Kecamatan Mengwi Kabupaten Badung. Salah satu solusi yang dapat digunakan untuk mengatasi permasalahan rendahnya hasil belajar adalah menggunakan model pembelajaran Group Investigation (GI). Model pembelajaran Group Investigation adalah "salah satu bentuk model pembelajaran kooperatif yang memiliki titik tekan pada partisipasi dan aktivitas siswa untuk mencari sendiri materi atau segala sesuatu mengenai materi pelajaran yang akan dipelajari informasi tersebut biasanya di dapat dari bahan-bahan yang tersedia" (Imas Kurniasih, dkk. 2015; Wisnawa, dkk., 2016). Menurut Killen (dalam Aunurrahman, 2012) yang berpendapat bahwa, "model investigasi kelompok merupakan cara yang langsung dan efisien untuk mengajarkan pengetahuan akademik sebagai suatu proses sosial". Jadi, model pembelajaran GI merupakan model pembelajaran yang pada penerapannya membagi siswa menjadi beberapa kelompok yang beranggotakan $2-6$ orang, tiap kelompok bebas memilih subtopik dari pokok bahasan yang akan diajarkan dan kemudian membuat laporan kelompok, setiap kelompok mempresentasikan laporannya kepada seluruh kelas untuk berbagi dan saling bertukar informasi temuan mereka. Model pembelajaran Group Investigation (GI) akan mampu menumbuhkan kehangatan hubungan antar pribadi, kepercayaan, rasa hormat terhadap aturan dan kebijakan, kemandirian dalam belajar serta homat terhadap harkat dan martabat orang lain, serta sisa lebih aktif dalam belajar.

Pembelajaran Group Investigation sangat baik digunakan untuk mengembangkan penyelidikan penyelidikan akademik, integrasi sosial, dan proses sosial dalam belajar (Suastra, 2009). Sejalan dengan pendapat Slavin (2008) yang menyatakan, pembelajaran kooperatif tipe Group Investigation (GI) meletakkan dasar pada psikologi pendidikan John Dewey, yang mana dia percaya bahwa para siswa akan mengalami pembelajaran bermakna jika mereka mampu menunjukkan langkah-langkah penyelidikan ilmiah Melalui penerapan Model pembelajaran Group Investigation ini, tentunya siswa dituntut untuk berpikir kreatif agar permasalahan yang diteliti dapat ditemukan jawabannya, hal tersebut sejalan dengan pendapat Gangoli (dalam Suma dkk., 2001) yang menyatakan "kegiatan penyelidikan dalam pembelajaran IPA ditujukan untuk mengembangkan keterampilan-keterampilan ilmiah, pemahaman konsep, kemampuan kognitif, berpikir kreatif, dan sikap ilmiah. Dan yang lebih penting lagi adalah bahwa investigasi kelompok dapat dipergunakan pada seluruh areal subyek yang mencangkup semua anak pada segala sekolah. Oleh sebab itu penerapan model ini untuk proses pembelajaran bagi siswa diyakini penting untuk dilakukan serta akan memberikan manfaat langsung bagi siswa dalam menggali pengalaman belajar mereka.

Rumusan masalah dalam penelitian ini adalah apakah penerapan model pembelajaran Group Investigation (GI) dapat meningkatkan hasil belajar IPA siswa kelas V SD No. 1 Abianbase Kecamatan Mengwi Kabupaten Badung tahun pelajaran 2016/2017. Tujuan penelitian ini adalah untuk mengetahui peningkatan hasil belajar belajar IPA setelah penerapan model pembelajaran Group Investigation (GI) pada siswa kelas V SD No. 1 Abianbase Kecamatan Mengwi Kabupaten Badung tahun pelajaran $2016 / 2017$.

\section{Metode}

Subjek penelitian ini adalah siswa kelas V SD No. 1 Abianbase yang berjumlah 33 orang. Objek penelitian ini adalah hasil belajar siswa setelah diterapkan model pembelajaran Group Investigation (GI). Penelitian ini merupakan penelitian tindakan kelas. Penelitian Tindakan Kelas (PTK) atau classroom action research. Penelitian tindakan kelas adalah penelitian yang mengangkat masalah-masalah aktual yang berupa tindakan untuk memperbaiki dan meningkatkan praktek pembelajaran di kelas secara lebih profesional" (Taniredja, 2011).

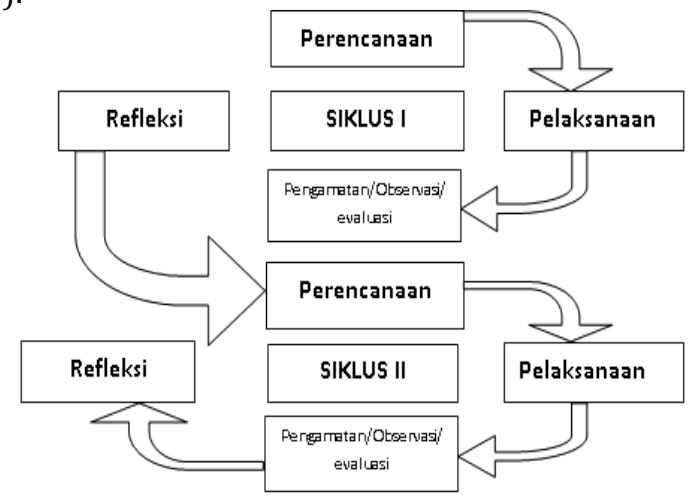

Gambar 1. Modifikasi Rancangan Penelitian Tindakan Kelas (Arikunto dkk., 2015) 
Penelitian tindakan kelas ini dirancang dalam 2 (dua) siklus. Setiap siklus terdiri dari 3 (Tiga) kali pertemuan. Setiap siklus terdiri dari 4 (empat) tahapan, yaitu perencanaan, pelaksanaan/tindakan, observasi/evaluasi, dan refleksi (Arikunto, dkk., 2015). Adapun rancangan penelitian ini, dapat dilihat pada gambar 1.

Metode pengumpulan data dalam penelitian ini yaitu dengan menggunakan metode tes dan observasi. Metode tes digunakan untuk mengukur ranah kognitif. Tes diberikan pada setiap akhir pertemuan pada masing-masing siklus. Sedangkan metode observasi digunakan untuk mengamati secara sistematis tentang sikap dan aktivitas ataupun kegiatan siswa dalam proses pembelajaran. Data hasil belajar IPA dianalisis secara deskriptif kuantitatif. Hasil perhitungan persentase yang diperoleh selanjutnya akan dikonversikan kedalam PAP skala lima sesuai Tabel 1.

Tabel 1. Pedoman konversi PAP Skala Lima tentang Peningkatan Hasil Belajar IPA

\begin{tabular}{cc}
\hline Persentase & Kriteria Hasil Belajar IPA \\
\hline $90-100$ & Sangat tinggi \\
$80-89$ & Tinggi \\
$65-79$ & Sedang \\
$55-64$ & Rendah \\
$0-54$ & Sangat rendah \\
\hline
\end{tabular}

Kriteria keberhasilan adalah standar yang ditetapkan sebagai acuan patokan atau tolak ukur keberhasilan. Penelitian dinyatakan berhasil jika tercapainya rata-rata skor siswa minimal 74 secara individu dan tercapainya ketuntasan belajar minimal 75\% secara klasikal.

\section{Hasil dan Pembahasan}

Penelitian ini merupakan penelitian tindakan kelas. Subjek penelitian ini adalah siswa kelas V SD No.1 Abianbase tahun pelajaran 2016/2017 yang berjumlah 33 orang. Mata pelajaran yang digunakan dalam penelitian ini adalah IPA dengan menggunakan model pembelajaran group investigation. Setiap siklus dilakukan dalam tiga kali pertemuan yaitu yaitu 2 (dua) kali pertemuan untuk pelaksanaan kegiatan pembelajaran dan 1 (satu) kali pertemuan untuk evaluasi hasil belajar siswa.

Sebelum diterapkannya pembelajran koopertif, digunakan metode konvensional yang hanya berpusat pada guru. Pembelajaran lebih didominasi oleh guru dibandingkan dengan siswa. Peran serta siswa dalam pembelajaran masih pasif tanpa terlibat secara langsung dalam pembelajaran. Siswa hanya mendengarkan penjelasan dari guru tanpa ada umpan balik ataupun interaksi antara guru dengan siswa. Dari hasil tes awal hasil siswa masih tergolong rendah yaitu rata-rata 59\%.

Pelaksanaan tindakan siklus I pertemuan pertama dilaksanakan pada tanggal 13 Oktober 2016 dengan materi sifat bahan dan hubungan sifat bahan dengan struktur penyusunnya, pertemuan kedua dilaksanakan pada tanggal 14 Oktober 2016 dengan materi jenis-jenis bahan penyusun benda dan tes hasil belajar IPA dilaksanakan pada tanggal 20 Oktober 2016.

Hasil observasi yang dilaksanakan setiap pembelajaran berlangsung, ditemukan bahwa hasil belajar siswa masih rendah, hal tersebut disebabkan karena dalam melakukan diskusi siswa masih mainmain dan hanya mengandalkan satu orang teman saja, siswa masih malu-malu untuk menjawab pertanyaan yang diajukan, dan kurangnya variasi media yang digunakan guru sehingga siswa merasa jenuh dan bosan untuk mengikuti pembelajaran. Refleksi dilaksanakan pada akhir siklus I, pedoman yang digunakan dalam refleksi ini adalah lembar observasi, hasil pekerjaan LKS siswa secara berkelompok, dan evaluasi hasil belajar siswa secara individual. Pada siklus I, hasil belajar yang diperoleh siswa sudah ada peningkatan dari refleksi awal sebelum dilaksanakan tindakan. Tetapi, hasil belajar tersebut masih perlu ditingkatkan karena belum mencapai kriteria yang ditargetkan, hal ini disebabkan siswa belum beradaptasi dengan proses pembelajaran secara berkelompok. Adapun kendala-kendala yang dihadapi peneliti dalam pelaksanaan siklus I adalah: (1) siswa belum terbiasa belajar secara berkelompok, sehingga siswa yang berkemampuan lebih mendominasi proses diskusi, (2) proses diskusi terkadang berlangsung ribut karena siswa belum terlatih belajar secara berkelompok.

Berpijak dari kendala-kendala yang dihadapi pada siklus I, dicari alternatif penyelesaian untuk mengatasi permasalahan serta kendala yang muncul pada siklus I yang kemudian disempurnakan pada siklus II. Perbaikan tindakan yang dilakukan adalah: (1) menjelaskan kembali kepada siswa langkahlangkah pembelajaran GI, (2) menyediakan benda-benda konkret kepada siswa serta melakukan demonstrasi tentang perubahan sifat benda, (3) memberikan dukungan kepada siswa untuk lebih bekerjasama dalam kelompoknya masing-masing dalam hal melakukan investigasi kelompok, penyelesaian tugas, dan penyampaian hasil diskusi, (4) membiasakan siswa untuk berlatih 
menyampaikan pendapat dengan mengajukan beberapa pertanyaan diskusi dan menghargai pendapat teman, (5) melatih siswa untuk menarik kesimpulan berdasarkan hasil diskusi.

Pada siklus II pertemuan pertama dilaksanakan pada tanggal 21 Oktober 2016 dengan materi perubahan sifat benda, pertemuan kedua dilaksanakan pada tanggal 27 Oktober 2016 dengan materi penyebab terjadinya perubahan sifat benda dan tes hasil belajar IPA dilaksanakan pada tanggal 28 Oktober 2016.

Hasil observasi yang dilaksanakan setiap pembelajaran siklus II, ditemukan bahwa dengan penerapan model pembelajaran gruop investigation hasil belajar siswa sudah meningkat. Temuan-temuan yang diperoleh selama tindakan pelaksanaan siklus II adalah secara garis besar proses pembelajaran siswa dapat berjalan sesuai dengan rancangan pembelajaran yang direncanakan peneliti, sehingga hasil belajar yang diharapkan dapat tercapai. Kondisi pembelajaran pada siklus II ini tampak lebih kondusif. Siswa telah beradaptasi dengan proses pembelajaran secara berkelompok dengan menerapkan langkahlangkah model pembelajaran GI dengan melihat secara langsung perubahan sifat yang terjadi pada suatu benda. Siswa sudah mulai terbiasa, aktif, mampu bekerjasama pada saat berdiskusi dan berkelompok dalam menyelesaikan permasalahan sesuai dengan topik yang telah ditentukan.

Segala permasalahan yang terjadi pada siklus I berdasarkan hasil refleksi siklus I relatif sudah teratasi dan hasil belajar siswa telah meningkat dan mencapai kriteria keberhasilan. Penelitian bahkan telah melebihi sehingga penelitian ini dapat dihentikan hingga siklus II. Secara garis besar, pembelajaran sudah sesuai dengan yang direncanakan sebelumnya. Siswa yang sebelumnya belum terbiasa belajar dengan menggunakan model pembelajaran, menjadi terbiasa belajar dengan model pembelajaran khususnya model pembelajaran group investigation.

Dari pelaksanaan tindakan yang telah dilakukan dengan menggunakan model pembelajaran group investigation maka hasil belajar IPA siswa kelas V SD No. 1 Abianbase, Kecamatan Mengwi, Kabupaten Badung dapat dilihat pada tabel 2.

Tabel 2. Ringkasan Persentase Rata-rata Hasil Belajar IPA pada Siklus I dan Siklus II

\begin{tabular}{ccc} 
Tahap & $\begin{array}{c}\text { Persentase Rata-rata Hasil } \\
\text { Belajar IPA }\end{array}$ & Kategori \\
\hline Siklus I & $66,67 \%$ & Sedang \\
Siklus II & $90,91 \%$ & Sangat tinggi \\
\hline
\end{tabular}

Perbaikan yang dilakukan pada siklus II ini mampu meningkatkan rata-rata aktivitas siswa. ratarata hasil belajar siswa pada siklus I pertemuan I sebesar $66,67 \%$ telah meningkat pada siklus II menjadi $90,91 \%$. Hal tersebut membuktikan hasil belajar siswa jika dilihat dari tiap pertemuan dari siklus I sampai siklus II terus meningkat dan sudah memenuhi kriteria keberhasilan yang ditentukan, yaitu 74 secara individu dan $75 \%$ secara klasikal.

Model pembelajaran Group Investigation (GI) menuntut siswa agar tidak hanya menerima materi yang diberikan tetapi menemukan konsep dari materi yang diberikan dengan pembelajaran kooperatif. Selain itu dengan model pembelajaran Group Investigation (GI) ini diharapkan siswa yang memiliki kemampuan lebih, mau membantu siswa yang memiliki kemampuan kurang karena model pembelajaran tidak hanya menekankan pada kemampuan individu tetapi juga menekankan pada kemampuan kelompok. Model pembelajaran Group Investigation merupakan model pembelajaran yang secara langsung dan efisien mampu mengajarkan pengetahuan akademik sebagai suatu proses sosial (Aunnurahman, 2012). Model ini juga akan mampu menumbuhkan kehangatan hubungan antar pribadi, kepercayaan, rasa hormat terhadap aturan dan kebijakan, kemandirian dalam belajar serta homat terhadap harkat dan martabat orang lain. Dan yang lebih penting lagi adalah bahwa investigasi kelompok dapat dipergunakan pada seluruh areal subyek yang mencangkup semua anak pada segala sekolah. Oleh sebab itu penerapan model ini untuk proses pembelajaran bagi siswa diyakini penting untuk dilakukan serta akan memberikan manfaat langsung bagi siswa dalam menggali pengalaman belajar mereka.Siswa dituntut untuk selalu aktif dalam menggali suatu informasi dan pengetahuan dari berbagai sumber, baik dari buku-buku sumber yang relevan, diskusi maupun tanya jawab bersama teman satu kelompok, ataupun guru. Ini berarti, siswa aktif mengkonstruksi pengetahuannya sendiri, sehingga pemahaman konsep, kemampuan penalaran dan komunikasi, serta pemecahan masalah siswa dapat ditingkatkan yang nantinya akan mampu memberikan kontribusi juga pada peningkatan hasil belajar.

Hasil penelitian yang telah dilakukan ini menunjukan bahwa penerapan model pembelajaran group investigation dapat meningkatkan hasil belajar IPA siswa kelas V SD No. 1 Abianbase. Berdasarkan hasil penelitian, persentase rata-rata hasil belajar siswa secara individu pada siklus I adalah $68,79 \%$. Jika dikonversikan berdasarkan PAP skala lima, maka hasil belajar yang diperoleh pada siklus I berada pada 
kategori sedang dan persentase rata-rata hasil belajar siswa secara klasikal pada siklus I adalah 66,67\%. Jika dikonversikan berdasarkan PAP skala lima, maka hasil belajar yang diperoleh pada siklus I berada pada kategori sedang. Selanjutnya, persentase rata-rata hasil belajar siswa pada siklus II secara individu adalah 79,69. Jika dikonversikan berdasarkan PAP skala lima, maka hasil belajar yang diperoleh pada siklus II berada pada kategori tinggi dan hasil belajar siswa secara klasikal pada siklus II adalah 90,91\%. Jika dikonversikan berdasarkan PAP skala lima, maka hasil belajar secara klasikal yang diperoleh pada siklus II berada pada kategori sangat tinggi. Jadi hasil belajar IPA siswa kelas V SD No. 1 Abianbase pada siklus II berada pada kategori tinggi secara individu dan hasil belajar IPA secara klasikal siswa kelas V SD No. 1 Abianbase pada siklus II berada pada kategori sangat tinggi.

Berdasarkan data di atas, penerapan model pembelajaran group investigation dapat meningkatkan hasil belajar IPA siswa kelas V SD No. 1 Abianbase. Hasil belajar siswa secara individu mengalami peningkatan dari kategori sedang ke kategori tinggi setelah melalui dua siklus dan hasil belajar siswa siswa secara klasikal mengalami peningkatan dari kategori sedang ke kategori sangat tinggi setelah melalui dua siklus. Peningkatan hasil belajar siswa disebabkan oleh beberapa faktor. Pertama, pelaksanaan proses pembelajaran menggunakan model pembelajaran group investigation menyebabkan siswa antusias mengikuti pembelajaran. Model pembelajaran ini mengajak siswa terlibat langsung dalam proses pembelajaran melalui kegiatan mengurutkan diskusi dan melakukan investigasi. Siswa menjadi lebih tertarik dengan kegiatan yang melibatkan siswa itu sendiri dibandingkan dengan mendengarkan penjelasan dari guru. Siswa diberikan kesempatan untuk berdiskusi dan saling berbagi informasi dalam belajar kelompok, sehingga dapat menumbuhkan interaksi yang aktif antara siswa dengan guru maupun dengan siswa itu sendiri. Minat, bakat serta motivasi siswa untuk belajar menjadi lebih tinggi dan meningkat. Tingkat kecerdasan, minat siswa, bakat siswa, dan motivasi siswa merupakan salah satu faktor fisiologis yang mempengaruhi hasil belajar siswa (Syah, 2006).

Faktor kedua adalah guru memberikan kesempatan siswa untuk menyampaikan pendapat, berdiskusi, dan mencari tahu kebenaran dari tugas yang dibuat dengan cara bertanya maupun mengemukakan ide yang mereka miliki. Kegiatan ini membuat siswa menjadi lebih memahami apa yang mereka pelajari karena siswa mencari tahu sendiri kebenaran tugas tersebut. Pendapat tersebut sejalan dengan pendapat Gagne (dalam Roestiyah, 1994) menyebutkan bahwa "pada proses belajar mengajar terdapat beberapa komponen yang menunjang proses belajar mengajar dan menentukan organisasi pengelolaan interaksi belajar mengajar, serta hasil belajar".

Ketiga, penggunaan media pembelajaran secara konkret dimana siswa bisa secara langsung bisa mengamati terjadinya perubahan sifat suatu benda serta sifat suatu benda dipengaruhi oleh struktur penyusunnya. Media pembelajaran dapat meningkatkan minat dan memotivasi siswa, sehingga siswa akan lebih bersemangat dan berperan aktif untuk mengikuti proses pembelajaran. Media pembelajaran juga dapat membantu siswa menyerap materi yang dipelajari lebih mendalam dan utuh.

Faktor yang terakhir adalah siswa belajar berdiskusi dengan anggota kelompoknya serta melakukan investigasi atau memecahkan permasalahan yang sudah diperoleh, permasalahan tersebut bisa diperoleh dari berbagai sumber. Hal tersebut sejalan dengan pendapat Suryabrata (2007) yang menyatakan bahwa salah satu faktor keberhasilan siswa dalam belajar yaitu alat-alat yang dipakai untuk belajar seperti alat tulis, buku, alat peraga, dan sumber belajar.

Selain itu, penelitian yang dilakukan oleh Ariadi (2014) yang berjudul "Pengaruh Model Pembelajaran Group Investigation (GI) Terhadap Hasil Belajar IPA Kelas IV SD No. 2 Belega Tahun Pelajaran 2013/2014. Dari hasil penelitian tersebut menjelaskan bahwa terdapat perbedaan hasil belajar IPA yang signifikan antara kelompok siswa yang mengikuti model pembelajaran group investigation dengan kelompok siswa yang mengikuti model pembelajaran konvensional. Hal ini ditunjukkan oleh (>) dan di dukung oleh perbedaan skor rata-rata yang diperoleh antara siswa yang mengikuti model pembelajaran kooperatif tipe group investigation yaitu 2,47 yang berada pada kategori baik dan siswa yang belajar menggunakan model pembelajaran konvensional yaitu 16,9 yang berada pada kategori cukup. Penelitian tersebut merupakan jenis penilitian eksperimen dan sampel yang diambil dengan cara random sampling. Data yang dikumpulkan dalam penelitian tersebut adalah hasil belajar IPA dengan bentuk tes pilihan ganda serta data dianalisi dengan menggunakan statistik deskriptif dan statistik inferensial.

Penelitian lainnya oleh Oka Budi Sriani (2016) yang berjudul” Penerapan Model Pembelajaran GI Dalam Pendekatan Saintifik Untuk Meningkatkan Hasil Belajar IPA siswa Kelas IVB SD Negeri 29 Pemecutan Tahun Ajaran 2015/2016. Dari hasil penelitian tersebut menunjukkan bahwa nilai hasil belajar IPA meningkat dari siklus I ke siklus II. Hal tersebut dibuktikan pada siklus I yakni 46,51\% dengan 20 siswa sudah berada pada kriteria ketuntasan minimal pada indikator keberhasilan yaitu 3,51 dengan kategori (A-). Rata-rata hasil belajar IPA ini sudah mengalami peningkatan dari prasiklus yaitu 30,31\%. Penelitian tersebut menggunakan metode tes dalam pengumpulan data. 
Berdasarkan uraian tersebut, penelitian ini dikatakan telah berhasil karena kriteria yang diterapkan sebelumnya telah terpenuhi. Jadi, dapat diinterpretasikan bahwa penerapan model pembelajaran Group Investigation (GI) dapat meningkatkan hasil belajar IPA siswa kelas SD No. 1 Abianbase, Kecamatan Mengwi, Kabupaten Badung tahun pelajaran 2016/2017.

\section{Simpulan dan Saran}

Kesimpulan dalam penelitian ini adalah pembelajaran Group Investigation (GI) dapat meningkatkan hasil belajar IPA siswa kelas V SD No. 1 Abianbase, Kecamatan Mengwi, Kabupaten Badung Tahun Pelajaran 2016/2017. Hal ini dapat terlihat dari peningkatan hasil belajar siswa dari siklus I sampai dengan siklus II. Pada siklus I, persentase rata-rata hasil belajar siswa sebesar $66,67 \%$, berada pada kategori sedang. Selanjutnya pada siklus II, persentase rata-rata hasil belajar siswa meningkat menjadi 90,91\%, berada pada kategori sangat tinggi.

Saran yang dapat disampaikan berdasarkan hasil penelitian tindakan ini adalah 1) bagi siswa, hasil penelitian ini agar memperoleh pengalaman belajar yang lebih bermakna serta siswa 2) bagi guru, hasil penelitian ini agar lebih meningkatkan pemahaman dan pengalaman dalam melakukan berbagai upaya untuk meningkatkan hasil belajar dengan penerapan model pembelajaran Group Investigation (GI), khususnya dalam mata pelajaran IPA dan mata pelajaran lain pada umumnya. 3) bagi kepala sekolah, hasil penelitian ini memiliki keterampilan untuk mengambil suatu kebijakan yang paling tepat dalam kaitan dengan upaya strategi pembelajaran yang efektif dan efisien di sekolah. 4) bagi peneliti lain, hasil penelitian ini untuk meneliti aspek atau variabel lain yang diduga memiliki kontribusi terhadap konsepkonsep dan teori-teori tentang model pembelajaran.

Dalam proses pembuatan skripsi ini, banyak bantuan yang diperoleh dari berbagai pihak. Oleh karena itu, pada kesempatan ini diucapkan terima kasih kepada yang terhormat Dr. Desak Putu Parmiti, M.S, yang selama ini telah memberikan arahan dan bimbingannya.

\section{Daftar Pustaka}

Agung, A. A. Gede. (2010). Pengantar Evaluasi Pendidikan. Singaraja: STKIP. Singaraja.

Ariadi, Putu. 2014. Pengaruh Model Pembelajaran Group Investigation (GI) Terhadap Hasil Belajar IPA Kelas IV SD No. 2 Belega. Tahun Ajaran 2013/2014. Skripsi (tidak diterbitkan). Jurusan Pendidikan Guru Sekolah Dasar, Universitas Pendidikan Ganesha.

Arikunto, Suharsimi, dkk. (2010). Penelitian Tindakan Kelas. Jakarta: Bumi Aksara

Aunnurahman. (2012). Belajar dan Pembelajaran. Bandung: Alfabeta.

Depdiknas. (2006). Peraturan Menteri Pendidikan Nasional No. 22Tahun 2006 Tentang Standar Isi Untuk Satuan Pendidikan Dasar dan Menengah. Jakarta:Departemen Pendidikan Nasional.

Depdiknas. (2008). Peraturan Menteri Pendidikan Nasional. Jakarta: Depdiknas

Devi, Poppy Kamalia. (2010). Metode-metode dalam Pembelajaran IPA untuk Guru SD. Jakarta: Pusat Pengembangan dan Pemberdayaan Pendidik dan Tenaga Kependidikan Ilmu Pengetahuan Alam (PPPPTK IPA), untuk Program Bermutu

Hasbullah. (2011). Dasar-dasar Ilmu Pendidikan. Jakarta: Rajagrafindo Persada.

Julianto, Suprayitno, dkk. (2011). Teori dan Implementasi model-model Pembelajaran Inovatif. Surabaya: UNESA.

Juniati, Ni Wayan., I Wayan Widiana. (2017). Penerapan Model Pembelajaran Inkuiri Untuk Meningkatkan Hasil Belajar IPA. Jurnal Ilmiah Sekolah Dasar. Vol.1 (1) pp. 20-29.

Kurniasih, I. \& B. Sani. (2015). Ragam Pengembangan Model Pembelajaran Untuk Peningkatan Profesionalitas Guru. Jakarta: Kata Pena.

Laba Laksana, Dek Ngurah. (2016). Miskonsepsi Dalam Materi IPA Sekolah Dasar. Jurnal Pendidikan Indonesia. Vol 6.No 2 tahun 2016. 
Oka Budi Sriani, Nyoman. (2016). Penerapan Model Pembelajaran GI Dalam pendekatan Saintifik Untuk Meningkatkan Hasil Belajar IPA Siswa Kelas IV B SD Negeri 29 Pemecutan Tahun Ajaran 2015/2016. Skripsi (tidak diterbitkan). Jurusan Pendidikan Guru Sekolah Dasar, Universitas Pendidikan Ganesha.

Puspitasari, Rika Nanda. (2009). Upaya Meningkatkan Prestasi Belajar IPA Siswa Kelas III melalui Penerapan Metode Guided Inquiry-Discovery. Skripsi Sarjana Pendidikan pada Fakultas Keguruan dan Ilmu Pendidikan Universitas Sebelas Maret, Surakarta: tidak diterbitkan.

Putrayasa, Ida Bagus. (2015). Pembelajaran Menulis Paragraf Deskripsi Berbasis Mind Mapping Pada Siswa Kelas Vii Smp Laboratorium Undiksha. Jurnal Pendidikan Indonesia. Vol. 2 No. 2.

Roestiyah, M.K. (1994). Masalah Pembelajaran Sebagai Suatu Sistem. Jakarta: Rineka Cipta.

Slavin, E. Robert. (2008). Cooperative Learning Teori Riset dan Praktik. Bandung ; Nusa Media

Suastra, I.W. (2009). Pembelajaran Sains Terkini: Mendekatkan Siswa denganLingkungan Alamiah dan Sosial Budayanya. Universitas Pendidikan Ganesha. Singaraja

Subagyo, Y., Wiyanto. dan Marwoto, P. (2009). Pembelajaran Sains dengan 126 Pendekatan keterampilan Proses untuk Meningkatkan Hasil Belajar Siswa. Jurnal Pendidikan Fisika Indonesia. 5(1): 60 -66.

Suma'mur. (2001). Pembelajaran IPA di SD, jakarta : CVHaji Masagung.

Suryabrata, Sumadi. (2007). Psikologi Pendidikan. Jakarta: PT Raja Grafindo Persada

Syah, Muhibbin. (2006). Psikologi Belajar. Jakarta: PT Grafindo Perkasa

Taniredja, Tukiran. (2011). Model-model Pembelajaran Inovatif. Bandung: Alfabeta.

Wijana, Nyoman. (2015). Pengaruh Pengintegrasian Pendidikan Karakter Berorientasi Kearifan Lokal Ke Dalam Materi Ajar Mata Kuliah Ilmu Lingkungan Untuk Meningkatkan Soft Skill Mahasiswa Jurusan Pendidikan Biologi Fmipa Undiksha. Jurnal Pendidikan Indonesia. Vol. 4, No.2. 645-657.

Widiana, I Wayan. (2016). Pengembangan Asesmen Proyek Dalam Pembelajaran IPA di Sekolah Dasar. Jurnal Pendidikan Indonesia Vol 6.No 2 tahun 2016. (http://ejournal.undiksha.ac.id/ index.php/JPI/article/view/8154).

Wisnawa, I. D. G. Raka, Ndara Tanggu Renda, I Wayan Widiana. (2016). Penerapan Model Pembelajaran GI (Group Investigation) Untuk Meningkatkan Hasil Belajar IPA Kelas IV. E-Journal PGSD Universitas Pendidikan Ganesha Mimbar PGSD Vol: 6 No: 3 Tahun 2016. 